\title{
Creativity in higher education of nursing - from the theoretical concepts to the pedagogical effects
}

\section{La creatividad en la educación superior en enfermería - de los conceptos teóricos a los efectos pedagógicos \\ Criatividade no ensino superior de enfermagem - dos conceitos teóricos aos efeitos pedagógicos}

Onã Silva ${ }^{1}$, Elioenai Dornelles Alves ${ }^{2}$, Maria Cristina Soares Rodrigues ${ }^{3}$

${ }^{1}$ Nurse, Public Health Specialist, Master of Education, PhD student in the Nursing Graduate Program at UnB (University of Brasilia). Works in the Health Department of the Federal District. Researcher at NESPROM-UnB and Playful Learning Group (UnB).

${ }^{2}$ Nurse, Doctor and Full Professor. Retired professor and Senior Researcher at University of Brasilia, Postgraduate Program in Nursing at UnB. Leader of the Nucleus of Studies in Education, Health Promotion and Inclusive Projects-CEAM/UnB,

Researcher at CNPq.

${ }^{3}$ Nurse, PhD in Health Science. Associate Professor of the Faculty of Health Science, Nursing Department and of the PPGEnf at UnB. Leader of the Group in Studies and Research Multidisciplinary in Patient Safety.

Cómo citar este artículo en edición digital: Silva, O; Alves, E. D; Rodrigues, M.C.S. (2014) Creativity in higher education of nursing - from the theoretical concepts to the pedagogical. Cultura de los Cuidados (Edición digital) 18, 40. Disponible en: http://dx.doi.org/10.7184/cuid.2014.40.05>

Correspondencia: QE 34, Conjunto R, Casa 36 - Guará II - Distrito Federal-Brasil- CEP 71065-182

Correo electrónico: onatil@gmail.com

Recibido: 09/07/2014; Aceptado: 16/11/2014

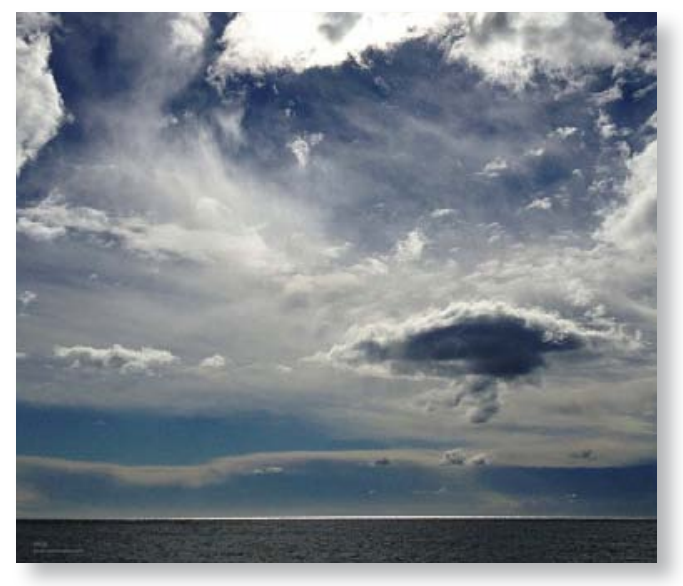

\section{RESUMEN}

Objetivo: Este artículo tiene el objetivo de reflexionar sobre la creatividad en la enseñanza de enfermería, fundamentando en teorías, discutiendo la aplicabilidad y los efectos pedagógicos creativos, en los actores educacionales.

Método: Se trata de estudio original de reflexión. El estudio fue conducido por el pensar reflexivo utilizando el operador cognoscente de la Teoría de la Complexidad, de Edgar Morin. Fueron seleccionadas teorías relacionadas a la creatividad y convergentes en el enfoque sociocultural: la Teoría en la Perspectiva de Sistemas, la Teoría General para el Desarrollo de la Productividad Creativa en Jóvenes y la Ciencia del Ser Humano Unitario.

Resultados: Las concepciones teóricas del estudio contribuyen para la producción de la ciencia referente a la creatividad en la educación superior de enfermería, superando las brechas científicas en la temática. Las teorías fundamentan y presentan relevancia científica a las investigaciones y a las evidencias pedagógicas. Efectos pedagógicos de la enseñanza basados en la creatividad, para los actores educacionales, docentes y estudiantes más identificados fueron autonomía, independencia, pensamiento divergente, ideas inusitadas, alegría y otros. 
Conclusión: Las concepciones teóricas de la creatividad contribuyen para el conocimiento de la enfermería, enriqueciendo las acciones cuidativas, desde la enseñanza, favoreciendo el potencial creador de los profesionales.

Palabras clave: Enfermería, Educación Superior, Creatividad, Investigación en Enfermería, Teoría de Enfermería.

\section{RESUMO}

Objetivo: Este artigo tem o objetivo de refletir sobre a criatividade no ensino de enfermagem, fundamentando em teorias, discutindo a aplicabilidade e os efeitos pedagógicos criativos, nos atores educacionais.

Método: Trata-se de estudo original de reflexão. Conduziu-se o estudo pelo pensar reflexivo utilizando o operador cognoscente da Teoria da Complexidade, de Edgar Morin. Selecionaram-se teorias relacionadas à criatividade e convergentes no enfoque sociocultural: a Teoria na Perspectiva de Sistemas, a Teoria Geral para o Desenvolvimento da Produtividade Criativa em Jovens e a Ciência do Ser Humano Unitário.

Resultados: As concepções teóricas do estudo contribuem para produção da ciência referente à criatividade no ensino superior de enfermagem, superando as lacunas científicas na temática. As teorias fundamentam e apresentam relevância científica às pesquisas e às evidências pedagógicas. Efeitos pedagógicos do ensino baseado na criatividade, para os atores educacionais, docentes e estudantes mais identificados foram autonomia, independência, pensamento divergente, ideias inusitadas, alegria e outros.

Conclusão: As concepções teóricas da criatividade contribuem para o conhecimento da enfermagem, enriquecendo as ações cuidativas, desde o ensino, favorecendo o potencial criador dos profissionais.

Palavras-chave: Enfermagem, Educação Superior, Criatividade, Pesquisa em Enfermagem, Teoria de Enfermagem.

\section{ABSTRACT}

Objective: This article aims to reflect on creativity in nursing education, basing on theories, discussing the applicability and pedagogical creative effects, in educational actors.

Method: It is the original study of reflection. The study was led by reflective thinking using the operator cognoscente of the complexity theory, by Edgar Morin. Related theories were selected for creativity and convergent in the sociocultural approach: the Theory on Systems Perspective, the General Theory for the Development of Creative Productivity in Young People and the Science of Unitary Human Being.

Results: The theoretical conceptions of the study contribute to production of science regarding creativity in higher education, overcoming the scientific gaps in the subject. The theories substantiate and present scientific relevance to the researches and to the pedagogical evidence. Pedagogical effects of teaching based on creativity, for educational actors, teachers and students most identified were autonomy, independence, divergent thinking, unusual ideas, joy and others.

Conclusion: The theoretical conceptions of creativity contribute to nursing knowledge, enriching the care actions, since the teaching, favoring the potential creator of professionals.

Keywords: Nursing, Higher Education, Creativity, Nursing Research, Nursing Theory.

\section{INTRODUCTION}

Everyone is creative and it is possible to rise the number of people with creative traits 
(Csikszentmihalyi, 1996) - this definition revolutionized science. First, for putting the creativity phenomenon in the scientific world by the Systemic Theory; second, the important ruptures with previous settings - the creativity related to thinking and personality traits, ignoring social influences.

The creativity, being a multifaceted construct, already presented distinct definitions. It was already considered from the magic and mysterious perspective - creative people were illuminated by gifts or inspiration -; seen as a complex sublimation repressed on Freud's view; as a promoter of mental health by humanists; and, more recently, conceptualized in a systemic perspective. In other words, the history of the research carried provides an overview of the multifaceted conceptual framework for creativity (Maslow, 1959; Rogers, 1978; Amabile, 1983; Csikszentmihalyi, 1992, 1996).

Defenders in the systemic vision argue that people become more creative influenced by multiple factors - people, social, cultural, spiritual and others - that are active and interrelated in the dimensions of complexity (Arieti, 1976; Csikszentmihalyi, 1988, 1992, 1996; Renzulli, 1992; Martinez, 2000).

Currently, by the emphasis on completeness, creativity is present in the research agenda. The purpose of the studies has been diversified: analysis of personalities, profiles, barriers and other objectives, more developed in the field of education and psychology.

As for the science of nursing, has produced few empirical studies. Those examined (Silva, 2013a), creativity doesn't appear as the main subject, but secondarily - often included in discussions of nursing education, basing the competencies, attitudes and skills - according to requirements established in the Undergraduate Program National Curriculum Standards in Nursing (NCSN) (Brasil, 2001).

Thus, creativity is related to the new profile of educational actors: the caring and educating that involves knowledge of creative nature, aesthetic, ethic, political and technical - qualifying educators for significant interventions in the care network (Ferraz et al, 2005; Erdmann et al, 2007); the approach to the training of nurses to care in any way, according to the model of health care whose directionality is to care for the user (Silva e Sena, 2006, 2008).

The authors who sign this consideration associates and researchers of nursing science - verified such scientific gaps (Silva, 2013a) - absence of thematic studies in creativity being, including, theme of the doctoral thesis of the first author.

Therefore, the objective of this study reflects on creativity in nursing education, basing on theories, discussing the applicability and effect of it, in educational actors.

\section{METHOD}

This is an original article of reflective nature. It was delineated in the reflection process, using a cognitive operator complex thinking the Reintroduction of the Principle of Cognoscente Subject, from Complexity Theory (Morin, 2005). This principle emphasizes the researcher as an observer in the action-reflection-action, for redefinition of knowledge, using its own cognitive potential, creative and subjectivities, favoring the reflection and the discussion of the state of the art of an object of study.

For the theoretical foundation of the study, three interrelated concepts that stand upon its precepts were selected - or allow us 
to discuss - the creative and playful aspects, inside the complex vision, in other words, the Perspective on the Theory of Systems (Csikszentmihalyi, 1996), General Theory for the Development of Creative Productivity in Young People (Renzulli, 1992) and the Science of Unitary Human Beings (Rogers, 1970).

\section{RESULTS}

From the theoretical referential about creativity, in the reflexive process, it was worked with knowledge that involves systemic nature. In other words, the ones related to the multiple humans potential - influenced and integrated -, such as creative experiences in scenarios and spaces promoters of the total development of the human being (Rogers, 1970; Arieti, 1976; Amabile, 1983; Csikszentmihalyi, 1988, 1992, 1996; Renzulli, 1992; Martinez, 2000).

This reflective act required an expanded analysis - systemic - about the creative potential. On the other hand, for methodological purposes, were delimited the theories and studies related to the creativity in teachinglearning process, that approach the man, as the results below exposed.

The Perspective on the Theory of Systems (Csikszentmihalyi, 1996) highlights in its grounds the social, cultural and personal forces. According to this theory, creativity should not be restricted to the mind, but it is the result of the interaction between the person's thinking and social-cultural context - in other words, the phenomenon is systemic before being individual. According to the theorist, it is impossible for man to live and interact excluding creativity, since the human being is naturally creative. To that end, the interest and creativity of people need to be revitalized in family, school and environmental experiences and the exposition to several opportunities.

The representation of Systemic Theory of Creativity can be visualized in Picture 1, in which appear three conceptual elements that are interrelated: the domain, the field and the individual.

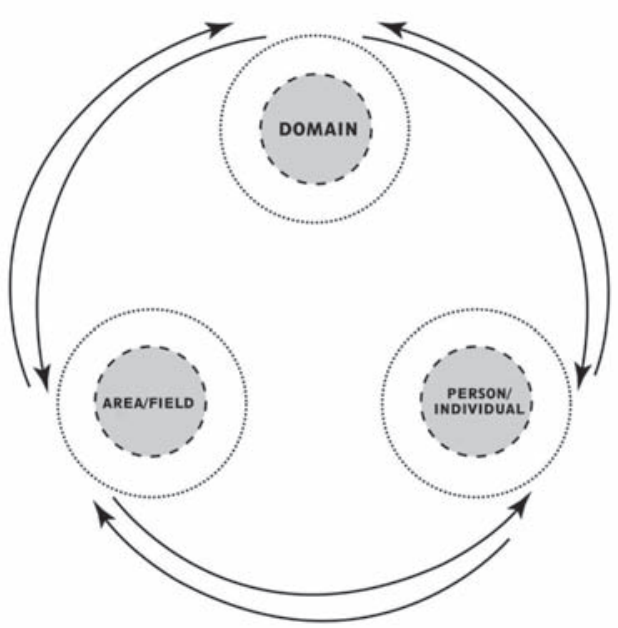

Picture 1-Schematic representation of the Perspective of Systems Theory of Creativity, Csikszentmihalyi, 1996 ${ }^{1}$.

However, the General Theory for the Development of Creative Productivity in Young People (Renzulli, 1992) emphasizes the interaction between social context and creative expression, aiming the creative production through learning. The main arguments refer to the encouragement of the creative production and the learning experiences.

The Picture 2 highlights the theoretical model represented by three circles - also called rings - that interact with themselves si-

${ }^{1}$ Schematic representation of the Systemic Theory created by the authors, based on the following: Csikszentmihalyi M. Creativity: Flow and the psychology of discover and invention. New York: HapperCollins; 1996. 
multaneously, corresponding to the structures of the teaching-learning process: teacher, student and curriculum.

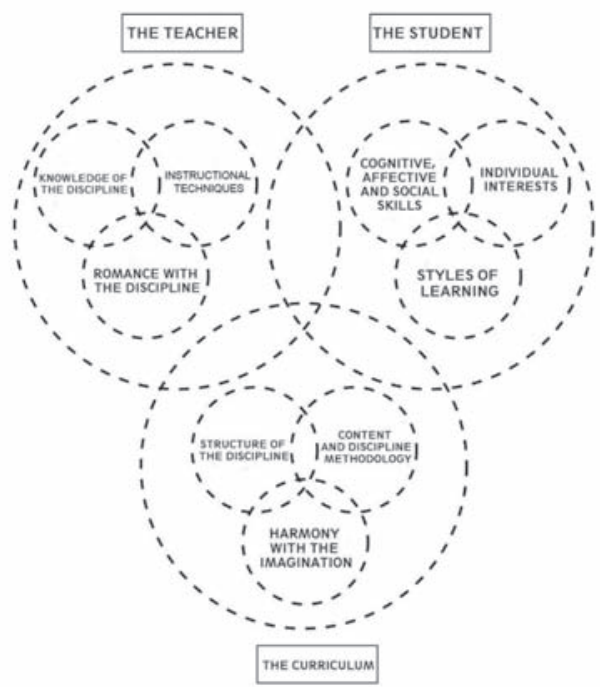

Picture 2- Schematic representation of the General Theory for the Development of Creative Productivity in Young People, Renzulli, $1992^{2}$

Regarding the Science of Unitary Human Beings (SUHB), created by a nurse (Rogers, 1970), highlights the basic concepts of vital process, unitary man, environmental energy fields, complementarity, principle of resonancy and principle of helicy.

In Roger's conception, nursing care promotes human development - the nurse is a vital participant in this process - and the knowledge field, constitutes, in fact, as humanist and humanitarian art-science. As instruments and values, the SUHB uses the imagination, creativity, the playfulness and the humanization.

The maximum paradigm of the theory is the emphasis on continuous and harmonious interaction between the person and the environment, the person being an open and unified, with biological, psychological, sociocultural and spiritual characteristics.

The Picture 3 highlights the continuous interaction that one can achieve, modifying the ideas, actions and behaviors, according to the precepts of the SUHB.

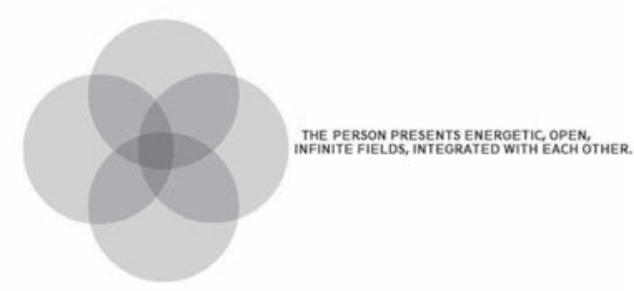

Picture 3- Schematic representation of the Science of Unitary Human Beings, Rogers, $1970^{3}$

\section{DISCUSSION}

Systemic theories of creativity: convergent aspects and the interrelationship with nursing

By confronting the selected theoretical concepts, it is observed that the convergence of these aspects refer to the argument that the expression of creativity involves different factors - social, historical, cultural. Consists in the history that two theories - Systemic and SUHB - were influenced by theories-sources, that is, the Systems Theory (Rogers, 1970; Csikszentmihalyi, 1996).

All of them systematize their assumptions on three or more aspects. The Systemic Theory emphasizes the interaction of three factors person/individual, domain, area/field -; the General Theory for the Development of Creative in Young People denominates the interactions as the three rings (or circles) - teacher,

\footnotetext{
${ }^{2}$ Schematic representation of the Theory created by the authors, based on the following source: Renzulli JS. A general theory for the development of creative productivity in young people. In: FJ Mönks, W Peters (Ed.). Talent for the future. Assen Maastricht-The Netherlands: Van Gorcum; 1992. p.51-72.

${ }^{3}$ Schematic representation of the Science of Unitary Human Beings created by the authors, based on the following source: Rogers ME. An introduction to the theoretical basis of nursing. Philadelphia, PA: F. A. Davis; 1970.
} 
student and curriculum -; and in the Science of Unitary Human Beings the interaction factors - the man and his environment - are mediated by the energy field and its open systems.

Basically, the theoretical concepts can be thereby understood:

a) The Systemic Theory can be explained by the interaction of three factors: the person/individual, the domain and the area/field (Csikszentmihalyi, 1996). Regarding the person is endowed with genetic background and personal experience. The creativity appears when it uses symbols of the domain (music, engineering and others) and its new idea is recognized by the area. The domain is the culture with their symbolic rules and procedures. The area or field is the social system that decides whether the new idea will be included in the field. It is the person who carries out changes in the field or area. Therefore, the creativity in this field is the interaction - domain, area and the person - being result of the opportunity, perseverance, to be in the right time and place.

b) The General Theory for the Development of Creative Productivity in Young People (Renzulli, 1992) is represented by three circles - also called rings - in simultaneous interaction, concerning the structures of learning: teacher, student and curriculum.

The first structure - the teacher - needs to know and like the discipline; to be the facilitator of the creativity, to have a less orthodoxy vision, enthusiasm for teaching, sense of humor and others. About the student - the second ring - the effective learning bases on individual interests, learning styles and cognitive skills, affective and social. The student must recognize his own skills, interests and learning styles; the school must involve them in activities related to the learning style of the students. The curriculum is the third ring represented by the triad: discipline structure, content and methodology discipline and harmony with the imagination. The desirable curriculum requires a project in which the student is an actor in the process.

c) The SUHB (Rogers, 1970) presents some main concepts. The person is defined as the unitary human being and integrated with the pan-dimensional (infinite); and in an open system in interaction with other system: the environment - the latter is an irreducible pandimensional energy field. Each field of the environment system is a human domain, and both evolve and interact mutually. Furthermore, the energy field patterns expressed defines the vital process, allows the observation of people and environments as irreducible entities, varying in intensity, density and length.

\section{The theoretical concepts and creativity re- flected in nursing education}

The three theories presented are the conceptions that can contribute a lot to the nursing, particularly to the nursing education, because its similar aspects are: highlight the creativity inherent to the unitary, global, full and complex nature person.

Such conceptions can contribute in teaching political projects of nursing education, as they are in accordance with the NCSN, which emphasizes the potentialities, the competence and the educational actors' skills: associate - facilitator; and student - the actor - of the learning process.

This way, the Systemic Theory and the three rings are clear in their assumptions by emphasizing that the personal characteristic and social-cultural environments - the school, in case - stimulate the creative production. They also stimulate the access and the updating of knowledge; access to mentors and diver- 
sified resources such as books, computers and an infinity of others.

Even being nursing theory, the SUHB has harmony with two others in analysis in this study, because it defines the person as open system, in development, dynamic and creative - nursing as a science and humanistic and humanitarian art, in the social context and complex in which it is inserted. The nurse helps people find their healthy potential. In education, the associate shares energy fields in peer relations and with students. In other words, the SUHB contributes to the practice, to the learning and research in nursing.

\section{Theoretical reflection of the pedagogical ef- fects of creativity in nursing education}

The development of creativity in the school context - including in higher education - it is an important element in the production of care, in the perspective of completeness, contributing to the continuous interaction of learning structures: the teacher, the student and the curriculum. For the actors of the educational area of nursing - teachers and students, no doubt that the development of the potential creator will reflect on the quality of teaching, favoring the personal enrichment, of the course, of the science, in favor of care to be developed in the user of the health system will receive quality care - involving aspects of humanization, of playful and health promotion. From this reflected practice that will emerge the positive pedagogical effects from nursing school based on creativity and with creativity - in which its actors use their potentials and expressions.

Undoubtedly the theories analyzed contribute for the development of the teaching. Regarding the nursing schools, it is important, to bring up a creative, critic, reflexive teachinglearning process. From this reflection formu- lated the concept of creativity as a revitalizing continuous wave that can be found in all contexts: social, family, professional and so many others (Silva, 2011, 2012). Finally, the theoretical foundation helps mediate the learning process, especially in the academic context, which is the source of scientific production.

In Brazil, among the ideas presented, few nurses have used the same applicability in health care, involving creativity (Sá, 1994; Baraúna, 2001; Silva, 2013a, 2013b). Among researchers, the ones that use SUHB corroborate the theoretical precepts that human life is a phenomenon of totality, continuity and creative and dynamic change. The person lies in open system, indivisible and creative. Thus, creativity is vital for nursing and the care act is expressed in a comprehensive and creative way, revitalized by intuitive professionals.

The first author of this reflection has been studying, applying and triangulating for more than two decades, the three theoretical concepts discussed here, the creative approach towards professional nursing (Silva, 2011, 2012, 2013b). In higher education in nursing area, the researcher has been dedicated to strategies, studies and productions with recognized innovations. It was mentioned the Cuidarte Project and the Creativity Space as strategies for developing expressive and creative skills, as well as studies of aesthetic knowledge involving poetry, music, theater, cordel literature and other artistic, expressive and cultural languages (Silva, 2011, 2013b, 2013c; Silva, Alves e Rodrigues, 2014; Siles González, 2014).

The applicability, presented in Picture 4, was developed by the first author, in workshops to stimulate creativity and development for nurses working to revitalize the energy fields aiming at health promotion, disease prevention and rehabilitation, which may be in 
care actions in various environments (parks, schools and health care network).

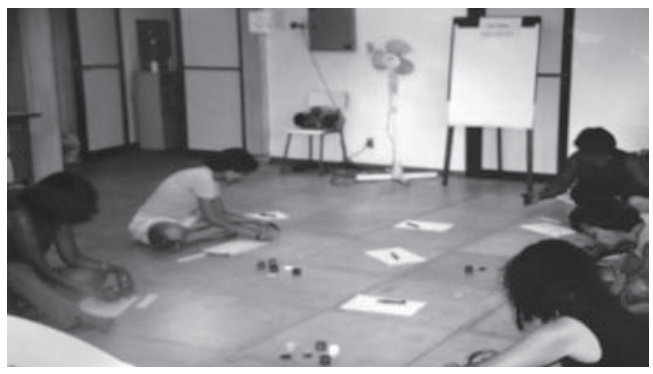

Picture 4- Creativity workshop for teachers in higher education. Digital collection of the first author ${ }^{4}$

As for the pedagogical effects that came from the creative teaching, emerges, for example, the development of expressive, musical, scenic, inter and intrapersonal relation, independence, fluency skills and divergent thinking, unusual ideas, happiness and many others.

From the theoretical conceptions presented, the higher nursing education based on creativity, provides the development of the creative potential of their educational actors, reflecting positively on care actions.

Thus, nursing education, based on theoretical conceptions of creativity in the educational scenario is very important, considering the challenges of care to be lived, built, reflected, involving the dimensions of complexity - indivisible spaces, solid and interaction spaces, open and meaningful.

\section{CONCLUSION}

The reflection allowed to analyze the importance of the three theoretical conceptions that enhance creativity in personal development and professional performance. It was emphasized, on reflection, nursing care in higher educational context. The theories pre- sent similar aspects in conceptual design - the systemic, extended and complex approach whose arguments turn to social-cultural scenarios, promoters of creativity, enhancing the creative potential of educational actors.

As for nursing, the reflection mediated by the systemic theories concluded that it lives up to the title of science-art, because of the constant interaction - person and environment - emerges the total care. This reflection also shows the need for research on the creativity and nursing themes - based on the theoretical concepts presented.

Studies whose main theme is creativity in nursing are scarce, also those of theoretical and creative base, including the SUHB whose paradigms have applicability in nursing care, with pedagogical purposes. The SUHB, being humanistic and humanitarian art and maximum pro-health of individuals, among its applicability, emphasizes creativity for both the individual and population groups.

The nursing science has concrete advantages when using theories that underpin the research. The challenge of the professionals is the scientific interface between theory, creativity and nursing for pedagogical purposes. But the challenge is the characteristic of the creative person and the researcher. May new researches be produced decreasing the gaps on the theme reflected.

\section{REFERENCES}

- Amabile, T.M. (1993) The social psychology of creativity. Springer-Verlag, New York.

- Arieti, S. (1976) Creativity: The magic synthesis. Basic Books, New York.

- Baraúna, T. (2001) Criatividade: uma necessidade para a enfermagem. Rev enf Nursing, 4(33): 8-9.

\footnotetext{
${ }^{4}$ Source: this Picture 4, which records creative activities for healthcare professional, belongs to the photo archive of the first
} author. 
- Brasil. (2001) Resolução CNE/CES 3/2001. Dispõe sobre as Diretrizes Curriculares Nacionais do Curso de Graduação em Enfermagem. Diário Oficial da União, Brasília, 9 de Novembro de 2001. Seção 1: 37.

- Csikszentmihalyi, M. (1988) The domain of creativity. Trabalho apresentado no Congresso de Criatividade. Ptizer College, Claremont, Estados Unidos.

- Csikszentmihalyi, M. (1992) A psicologia da felicidade. Saraiva, São Paulo.

- Csikszentmihalyi, M. (1996) Creativity: Flow and the psychology of discover and invention. Hap $\neg$ perCollins, New York.

- Erdmann, A.L; Sousa, F.G.M; Backes, D.S; Mello, A.L.S.F. (2007) Construindo um modelo de sistema de cuidados. Acta paul. Enferm 20(2):180-85.

- Ferraz, F; Silva, L.W.S; Silva, L.A.A; Reibnitz, K.S; Backes, V.M.S. (2005) Cuidar-educando em enfermagem: passaporte para o aprender/educar/cuidar em saúde. Rev bras enferm 58(5): 607-10.

- Martinez, A.M. (2000) Criatividade, personalidade e educação. Ed. Papirus, 2a ed. São Paulo

- Maslow, A.H. (1959) Creativity in self-actualizing people. In $\mathrm{HH}$ Anderson (Ed.). Creativity and its cultivation. Harper \& Row, New York: 83-95.

- Morin, E. (2005) Introducción al pensamiento complejo. Gedisa, Barcelona.

- Renzulli, J.S. (1992) A general theory for the development of creative productivity in young people. In: FJ Mönks, W Peters (Ed.). Talent for the future. Assen Maastricht- Van Gorcum, The Netherlands: 51-72.

- Rogers, C.R. (1978) Tornar-se pessoa. Martins Fontes, São Paulo.

- Rogers M.E. (1970) An introduction to the theoretical ba $\neg$ sis of nursing. F.A.Davis Company, Philadelphia:

- Sá, A.C. (1994) A ciência do ser humano unitário de Martha Rogers e sua visão sobre a criatividade na prática da enfermagem. Rev Esc Enfermagem USP 28(2):171-76.

- Siles González, J. (2014) Onã Silva (2013) Histórias da enfermagem no universo de cordel, Brasília, Thesaurus. 324 p/il. Cultura de los Cuidados (Edición digital). 18, 38:148-149. Disponible en: http://dx.doi.org/10.7184/ cuid.2014.38.20>
- Silva, K.L; Sena, R.R. (2006) A formação do enfermeiro: construindo a integralidade do cuidado. Rev bras enferm 59(4):488-91.

- Silva, K.L; Sena R.R. (2008) Integralidade do cuidado na saúde: indicações a partir da formação do enfermeiro. Rev Esc Enferm USP 42(1):48-56.

- Silva, O. (2001) A criatividade no ensino superior de enfermagem à luz dos componentes do processo en $\neg$ sinoaprendizagem: o professor, o aluno e o currícu $\neg$ lo [dissertação de Mestrado em Educação]. Universidade Católica de Brasília.103 f. Brasília (DF).

- Silva O. (2011) Espaço Criatividade. In: 63 Congresso Brasileiro de Enfermagem, organizador. (Re)criação e inovação do cuidado de enfermagem. $63^{\circ}$ Congresso Brasileiro de Enfermagem; 3 a 6 out 2011: Maceió, Al. Maceió: $63^{\circ} \mathrm{CBEn}$.

- Silva, O. (2012) Projeto Cuidarte: o ensino do curso de graduação em enfermagem revitalizado pela criatividade e arte. In: VII Congresso Iberoamericano de Docência Universitária, organizador. Ensino Superior: Inovação e Qualidade na Docência. VII Congresso Iberoamericano de Docência Universitária: Livro de Atas; 24 a 27 jun 2012: Porto, Portugal: 1055-56

- Silva, O. (2013a) As ondas revitalizadoras da criatividade no ensino de enfermagem: estudo comparativo e multifatorial do perfil criativo dos atores educacionais. Tese desenvolvida no Programa de Pós-Graduação em enfermagem. Universidade de Brasília. Brasília (DF).

- Silva, O. (2013b) A enfermagem nas ondas da criatividade e ludicidade: relato de experiência. In: Sá A.V.M., Silva A.J.N., Braga M.D., Silva O. (Org.). Ludicidade e suas interfaces. $1^{\mathrm{a} e d}$. Editora Liber Livro Ltda, BrasíliaDF: $17-38$.

- Silva, O. (2013c) Histórias da enfermagem no universo de cordel. $2^{\text {a }}$. ed. Thesaurus Editora de Brasília, BrasíliaDF: 324 .

- Silva, O; Alves, E. D; Rodrigues, M.C.S. (2014) Liricidad y toque de arte para la producción del conocimiento estético de enfermería - una reflexión poética inspirada en la Teoría de la Complejidad. Cultura de los Cuidados (Edición digital) 18, 39:14-29. Disponible en: http:// dx.doi.org/10.7184/cuid.2014.39.03> 